\title{
Use the Geonet in Erosion Control Works and Slope Stabilizations - A Sample Study
}

\author{
Emre ÇOMAKLI ${ }^{1}$, Yahya BULUT ${ }^{2}$
}

\begin{abstract}
Especially in recent years, geosynthetic materials are called "miracle materials" because they provide both useful and alternative solutions in engineering applications worldwide and their use is expanding swiftly. The purpose of the current research was to determine the soil holding capacity of geonet which is one of the geosynthetic materials in order to ensure more effective glacis stabilization in high sloping terrai*+ns. The Geonet product was tested and analyzed at a glacis with a slope of $74 \%$ within the boundaries of the district of Çamlidere of the province of Ankara. In this study, The success statues of the issue of erosion and the use of geonet were tackled. According to the results of the study, soil erosion decreased four fold with the use of the geonet product. Moreover, it has been thought that these applications contributed to the visual quality positively.
\end{abstract}

Keywords: Erosion, geosynthetic, geonet, slope stabilization.

\section{Erozyon Kontrolü Çalışmaları ve Şev Stabilizasyonlarında Geonet Kullanımı ve Örnek Bir Uygulama}

ÖZET: Geosentetik malzemeler özellikle son yıllarda, bütün dünyada dış mekan mühendislik uygulamalarında alternatif çözümler sağladıklarından 'kullanımları hızla yaygınlaşmaktadır. Bu çalışmada yüksek eğimli arazilerde şev stabilizasyonunu daha etkin olarak sağlamak amacıyla geosentetik malzemelerden geonet’in toprağı tutma kapasitesinin belirlenmesi amaçlanmaktadır. Ankara ili Çamlıdere ilçesi sınırları içerisinde \%74 eğimli bir şevde geonet ürünü denenerek araştırma yapılmıştır. Yapılan araştırmada geonet'in erozyon kontrolü konusunda başarı durumları incelenmiştir. Çalışma sonucuna göre geonet ürününün kullanımı ile toprak erozyonu 4 kat azaltılmıştır. Aynı zamanda bu uygulamaların görselliği olumlu etkilediği düşünülmektedir.

Anahtar Kelimeler: Erozyon, geosentetik, geonet şev stabilizasyonu,

Atatürk Üniversitesi, Çevre Sorunları Araştırma Merkezi, Erzurum,Türkiye

Atatürk Üniverstesi, Mimarlık Tasarım Fakültesi, Peyzaj Mimarlığı Bölümü, Erzurum Türkiye

Sorumlu yazar/Corresponding Author: Emre ÇOMAKLI, comakliemr@gmail.com 


\section{INTRODUCTION}

Soil of many countries is exposed to severe erosion all over the world. According to various studies, approximately 24 billion tons of soil are lost due to erosion every year, and the number is increasing day by day. The loss of soil causes a major problem especially in dry zones and ensures the zones to face the risk of being a desert.

In the world, there are 110 countries which are about to become deserts because of erosion. The United Nations Environment Programme (UNEP) calculated that the cost of desertification is approximately 42 billion dollars per annum (Anonim 2013a).

As sources about erosion are analyzed, the continent where erosion occurs the most around the world is Asia Continent which also involves Turkey. Unless required precautions are taken, the severity of erosion will get higher and higher. Thus, the world will rapidly become a desert and the rural poverty will relatively increase (Anonim 2013b).

Loss of soil in Turkey is mostly because of erosion like in other parts of the world. Erosion caused by humankind's intervention in nature results in serious problems as well as natural erosion caused by lay, climate, flora, and features of soil. $73 \%$ of Turkey's land is exposed to erosion. It is known that the amount of soil wasted from the country surface due to various causes in a year is about 1.4 million tons. Lands of the country take organic substances and minerals away with them while being eroded and moved (Anonim 2013c).

Soil carried from the field by streams in Turkey is in seven-fold of USA, in seventeen-fold of Europe, and in twenty two-fold of Africa. The Euphrates River carries 108 million tons of soil and Yesilirmak carries 55 million tons of soil per year.

32 million tons of soil are accumulated in the Keban Dam, and 31 million tons of soil are accumulated in the Karakaya Dam every year. 90 million tons of nutrient are lost as well as soil due to erosion per annum.

500 million tons of fertile topsoil from the cultivated area and 1.4 billion tons of fertile topsoil from all surface of the country are lost because of erosion every year.

The lost soils are equivalent to a terrain which is $25 \mathrm{~cm}$-thick and about 400 thousand hectareswidth (Anonim 2013c).

The loss of soil caused by erosion in Turkey is three out of 33 of erosion occuring in the world. In another word, while the amount of the lost soil caused by erosion per capita is 4 tons per annum, it is unfortunately 10 tons in Turkey (Dogan 2011).

The loss caused by wind and water is avoided with the erosion control. Geosynthetics enables violent planting in fields being exposed to erosion.

Various studies have been carried out in order to minimise the negative effects of erosion in Turkey, and successful results have been considerably obtained. Moreover, new techniques used for the erosion control in the world should be tested in Turkey.

\section{MATERIALS AND METHOD}

\section{Materials}

\section{1- The search site}

The search site is on the $30^{\text {th }} \mathrm{km}$ of the TEM highway between Ankara and Istanbul, $5 \mathrm{~m}$ inside of the path.

The research was done in a 900 square meter field next to the studies of avoidance of erosion already done by the General Directorate of Forestry (OGM) within the number 100 division boundries of Camlidere Department of Forestry Pecenek (Figure 1).

The search site is in the coordinates of $32^{\circ} 23^{\prime}$ 19.911" E $40^{\circ} 26^{\prime} 37.605^{\prime \prime N}$.q 


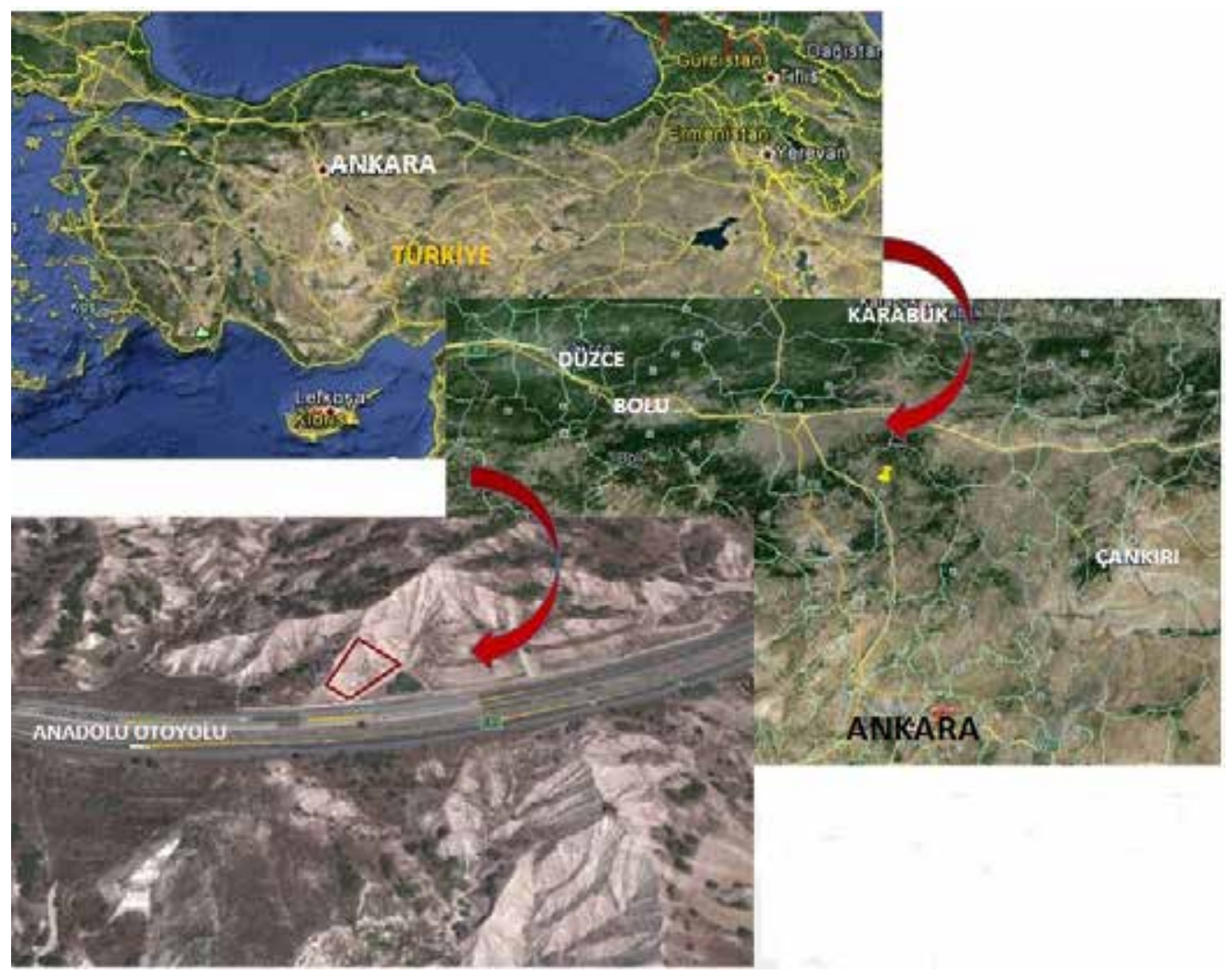

Figure 1. The Satellite image of the search site

\section{2-Research Materials}

\section{Geonet}

They are products generally made of polyethylene and used for drainage purposes thanks to their cavernous structures which make liquid transmission easy despite their resistance to some extent (Figure 2)(Table 1). It has been made up of a set of two polymer bars the gaps of which are about 6-30 mm. (Wasti 2007).

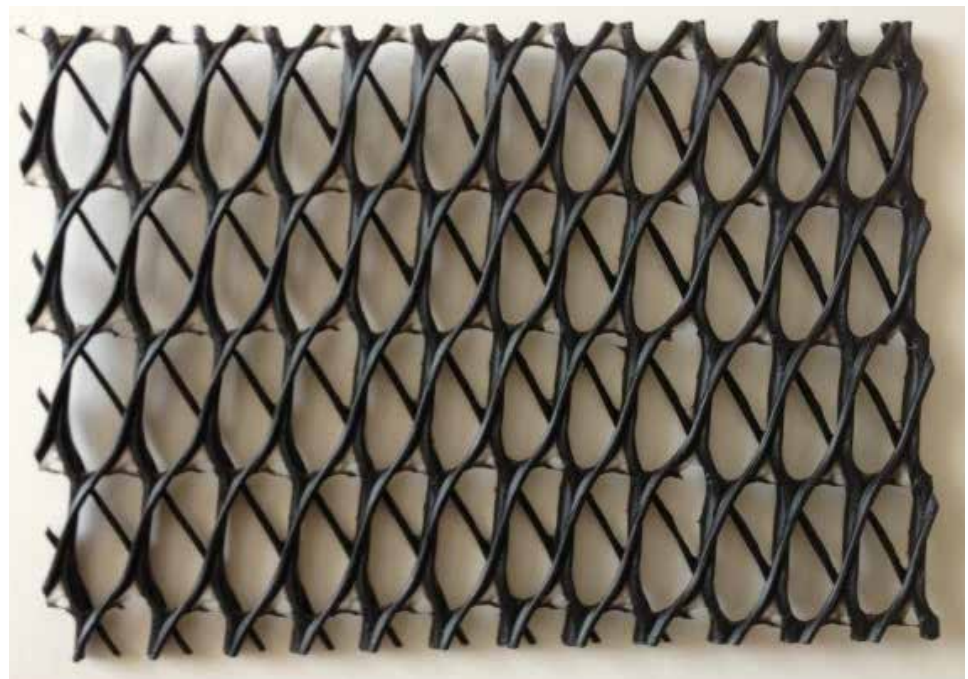

Figure 2. A sample of Geonet (Anonim 2013d)

The drainage of water leaking from surface and rock slopes, and the sub-drainage under soil embankments can be used for the purpose of avoidance of erosion on inclined surfaces (Myles 2006). 
Table 1. The features of Geonets

\begin{tabular}{|l|l|}
\multicolumn{1}{|c|}{ Physical Features } & \multicolumn{1}{c|}{ Mechanical Features } \\
\hline - Intensity & - The Tensile Strength \\
- Unit Weight & - The Compressive Strength \\
- Strip Dimensions & - The Cutting Force Strength \\
- The interstrip Angle & -The Flow Rate \\
-The Size and Shape of the cavernous & \\
\hline
\end{tabular}

\section{3- The Structure of Land}

It is stated that the apex of the slope chosen for the search site is $1132 \mathrm{~m}$. and the lowest height is $1110 \mathrm{~m}$.
The slope length in the site the inclination of which is about $74 \%$ is $30 \mathrm{~m}$. The site has a high inclination, is lack of flora, and is prone to erosion (Figure 3).

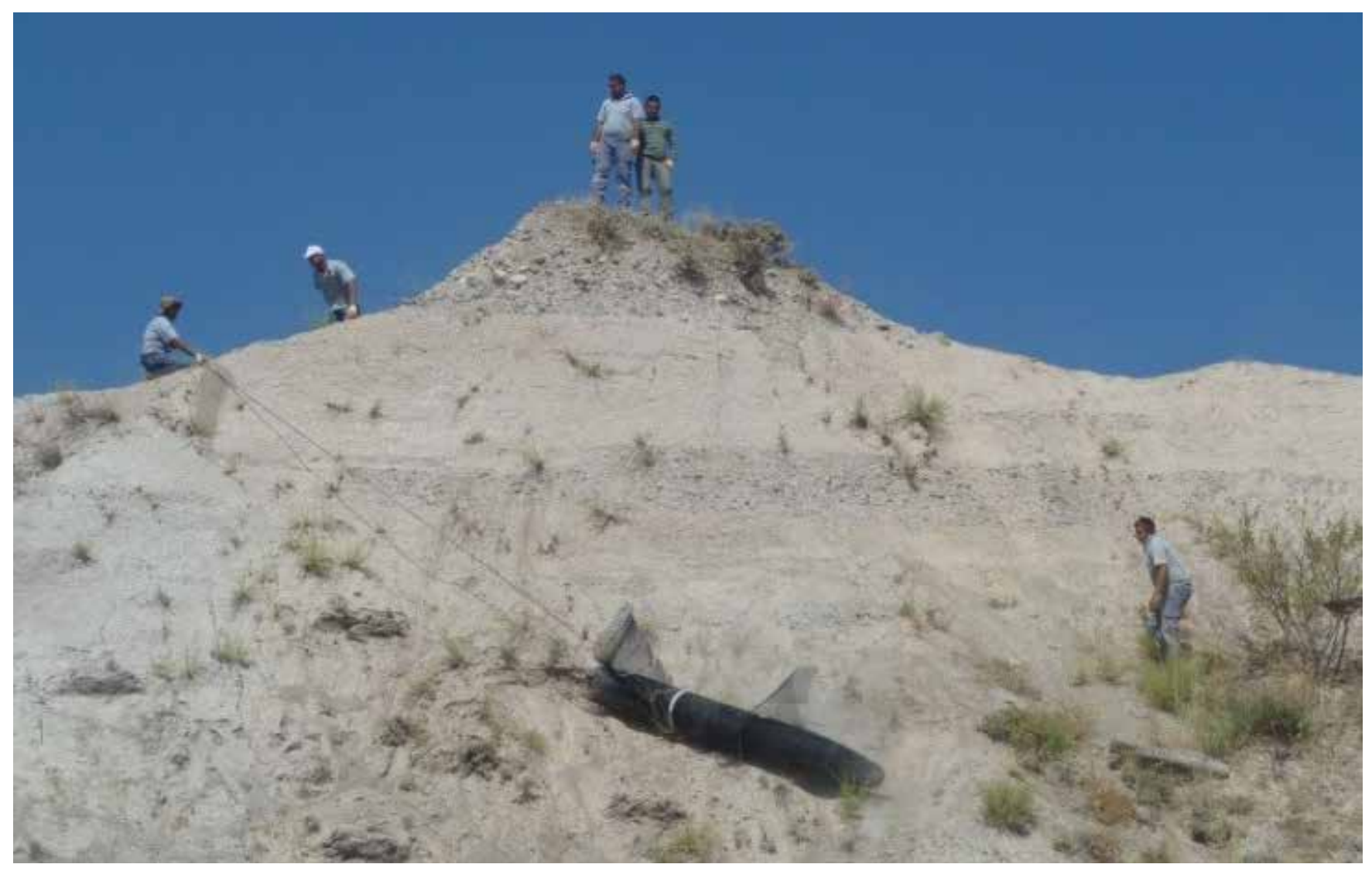

Figure 3. The search site

\section{4- The Features of Soil}

The field involving the search site has the characteristics of the step zone. According to the result of the analysis made from the sample of soil extracted from the search site, the texture of soil was stated as loamy clay, and the soil has a neutral character, is slightly lime-based, salt-free, and extremly lack of organic substances (Table 2). 
Table 2. The Table of the Soil Analysis

\begin{tabular}{|c|c|c|c|c|c|c|c|c|c|}
\hline \multicolumn{5}{|c|}{ PHYSICAL ANALYSES } & \multicolumn{5}{|c|}{ CHEMICAL ANALYSES } \\
\hline \multirow{3}{*}{$\underset{\%}{\text { Sand }}$} & \multirow{3}{*}{$\begin{array}{c}\text { Powder } \\
\%\end{array}$} & \multirow{3}{*}{$\underset{\%}{\text { Clay }}$} & \multirow{3}{*}{$\begin{array}{l}\text { The Type of } \\
\text { Soil } \\
\text { (According } \\
\text { to the } \\
\text { international } \\
\text { soil triangle) }\end{array}$} & \multirow{3}{*}{\begin{tabular}{|l}
$\mathbf{p H}$ \\
1.2 .5 \\
$\quad$ \\
$\quad$ Total \\
\\
$\quad \%$
\end{tabular}} & \multirow{2}{*}{ Lime } & \multirow{3}{*}{ Lime } & \multirow{3}{*}{$\begin{array}{c}\text { Organic } \\
\text { Substance } \\
\%\end{array}$} & \multirow{3}{*}{$\begin{array}{c}\text { Total } \\
\text { Azote } \\
\%\end{array}$} & \multirow{3}{*}{$\begin{array}{l}\text { Saltiness } \\
\mathrm{EC} 10^{3} \\
25 \mathrm{C}^{\circ} \\
\mathrm{mS} / \mathrm{cm}\end{array}$} \\
\hline & & & & & & & & & \\
\hline & & & & & $\begin{array}{c}\text { Active } \\
\%\end{array}$ & & & & \\
\hline 51,54 & 22,74 & 25,72 & Loamy Clay & 7,10 & 2,33 & - & 0,46 & 0,02 & 0,58 \\
\hline
\end{tabular}

\section{5- The Features of Climate}

The large part of fall is in winter and especially in spring. Early frost is in September, late frost lasts until the end of April (Table 4). As climatic data from Kizilcahamam Meteorological Station is examined,

a dry period is observed from mid June to the end of September. The majority of precipitation falls between December and May according to the average of many years (Table 3 ).

Table 3. Temperature Data of Months when a research was made according to data between 1970 and 2012 from Kizilcahamam Station.

\begin{tabular}{|l|c|c|c|c|c|c|c|c|c|}
\hline Parameter & Jan. & Feb. & Mar. & Apr. & May. & Sept. & Oct. & Nov. & Dec. \\
\hline Mean Temperature $\left({ }^{\circ} \mathrm{C}\right)$ & -1.1 & 0.2 & 4.2 & 9.2 & 13.9 & 16.3 & 10.8 & 4.7 & 0.7 \\
\hline $\begin{array}{l}\text { The Average of Maximum } \\
\text { Temperature }\left({ }^{\circ} \mathrm{C}\right)\end{array}$ & 3.1 & 5.0 & 10.0 & 15.3 & 20.3 & 24.2 & 18.1 & 10.8 & 4.8 \\
\hline $\begin{array}{l}\text { The Average of Minimum } \\
\text { Temperature }\left({ }^{\circ} \mathrm{C}\right)\end{array}$ & -4.8 & -4.1 & -1.3 & 3.2 & 7.0 & 8.6 & 4.6 & 0.0 & -2.9 \\
\hline $\begin{array}{l}\text { Days of Maximum } \\
\text { Temperature }\end{array}$ & 7 & 13 & 31 & 30 & 12 & 1 & 2 & 2 & 6 \\
\hline $\begin{array}{l}\text { The Year of Maximum } \\
\text { Temperature }\end{array}$ & 1971 & 1979 & 1975 & 1970 & 1970 & 2003 & 1999 & 2004 & 2008 \\
\hline Maximum Temperature $\left({ }^{\circ} \mathrm{C}\right)$ & 17.0 & 17.4 & 24.4 & 29.7 & 31.4 & 35.3 & 30.5 & 23.2 & 16.9 \\
\hline $\begin{array}{l}\text { The Difference of Maximum } \\
\text { Temperature on a Day }\left({ }^{\circ} \mathrm{C}\right)\end{array}$ & 20.6 & 21.2 & 22.6 & 22.0 & 24.4 & 25.2 & 24.4 & 23.6 & 20.8 \\
\hline
\end{tabular}

The effect of climate on erosion is with precipitation, temperature, and wind. One of the most important of them is precipitation, and the type, the intensity, the duration, and the antecedent of fall affect erosion differently. Especially in The Central Anatolia
Region involving the search site, summer drought and lack of rainfall are much more in comparison with other regions. Hence, the region lack of flora is one of the regions which are affected by erosion the most in Turkey. 
Table 4. The precipitation data of months when a research was made according to data between 1970 and 2012 from Kizilcahamam Station.

\begin{tabular}{|c|c|c|c|c|c|c|c|c|c|}
\hline Parameter & Jan. & Feb. & Mar. & Apr. & May. & Sep. & Oct. & Nov. & Dec. \\
\hline $\begin{array}{l}\text { The Average of Areal } \\
\text { Precipitation }(\mathrm{mm})\end{array}$ & 64.8 & 53.1 & 50.5 & 62.4 & 60.0 & 21.5 & 39.1 & 47.4 & 76.0 \\
\hline $\begin{array}{l}\text { Maximum Precipitation } \\
(\mathrm{mm})\end{array}$ & 51.5 & 41.1 & 40.6 & 45.7 & 40.4 & 54.8 & 40.5 & 58.4 & 54.6 \\
\hline $\begin{array}{l}\text { The Average of Days on } \\
\text { Which Precipitation is } 0.1 \\
\mathrm{~mm} \text { and higher. }\end{array}$ & 12.3 & 11.3 & 11.2 & 12.8 & 13.7 & 4.9 & 7.8 & 9.5 & 12.3 \\
\hline $\begin{array}{l}\text { The Average of Days on } \\
\text { Which Precipitation is } 10 \\
\mathrm{~mm} \text { and higher. }\end{array}$ & 2.0 & 1.6 & 1.5 & 1.7 & 2.0 & 0.6 & 1.2 & 1.6 & 2.4 \\
\hline $\begin{array}{l}\text { The Average of Days on } \\
\text { Which Precipitation is } 50 \\
\mathrm{~mm} \text { and higher. }\end{array}$ & 0.0 & & & & & 0.0 & & 0.0 & 0.0 \\
\hline The Number of Snowy Days & 8.4 & 7.2 & 4.8 & 1.1 & 0.1 & 0.0 & 0.2 & 2.2 & 6.2 \\
\hline $\begin{array}{l}\text { The Number of Snow- } \\
\text { Covered Days }\end{array}$ & 14.4 & 9.7 & 3.8 & 0.3 & 0.0 & & & 1.6 & 8.4 \\
\hline Maximum Snow Depth(cm) & 55 & 45 & 19 & 7 & 4 & & & 20 & 34 \\
\hline
\end{tabular}

\section{Method}

The research was made in a 900 square meter field which is along with the TEM highway between Ankara and Istanbul. The site was straightened with labor-power in September, 2012 first of all by weeding out of the search site. The geonet product which was brought in rolls to the site was applied approximately on three days by being unrolled from top to bottom (Figure 4). The site was divided into two and the geonet product was spread over 450 square meter. The rest of site was intented for the control panel.

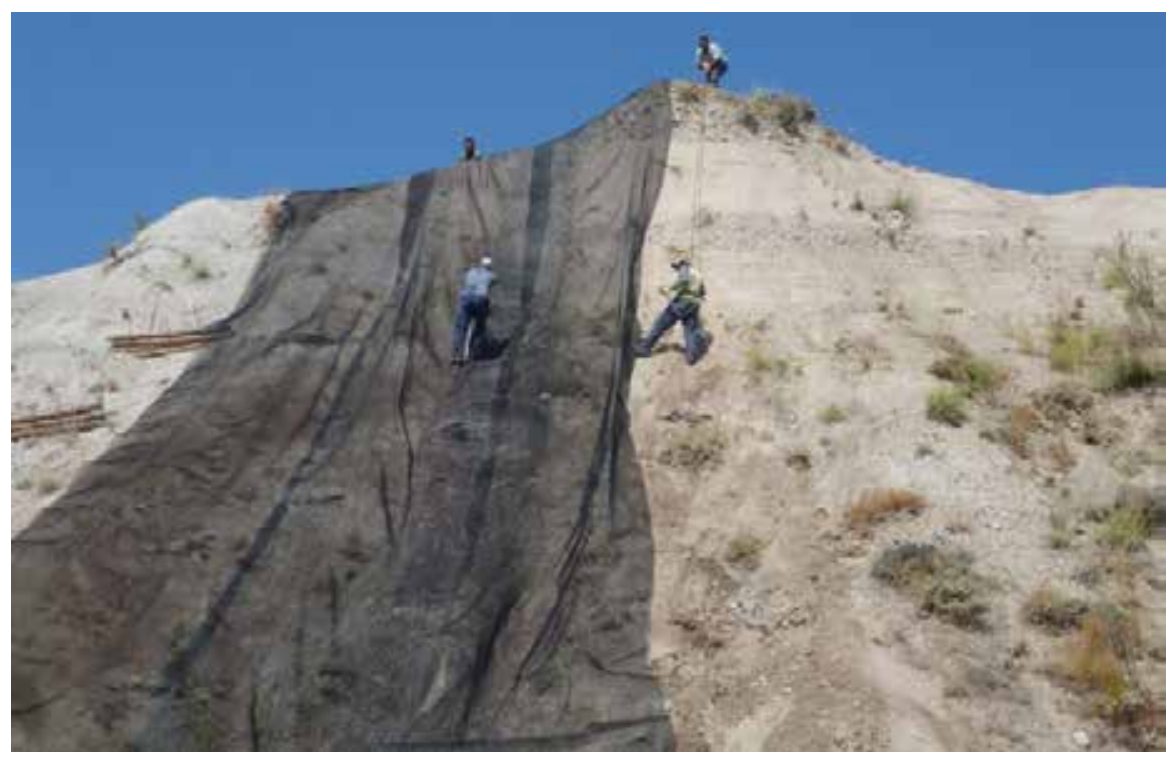

Figure 4. An image from the run phase of the geonet product 
In order to fix the geonet used as a cover material on the apex of slope, the product was fixed by diking $50 \mathrm{~cm}$. The dike was filled with soil. The outspread geonet should always stay in touch with the ground under it. To ensure that, tieback anchors were placed on every 2-3 square meter along with the surface of the slope (Figure 5).

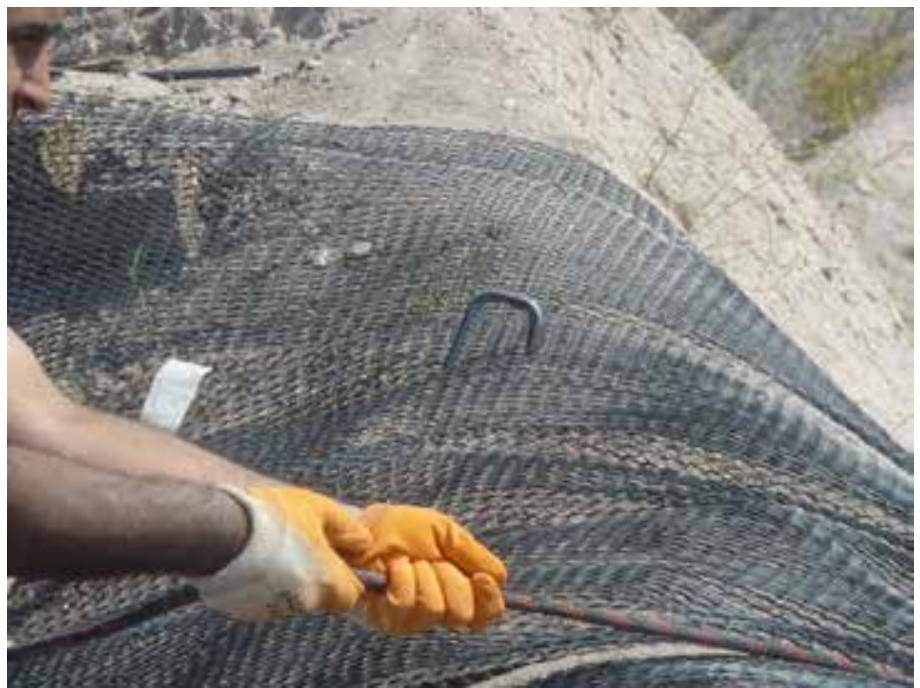

Figure 5. Laying of Tieback Anchors

A metal plate was fixed in semicylinder under the slope in an attempt to save and to measure soil leaking (Figure 6). Measurements were carried out bimontly and lasted 9 months. They started on September 10, 2012 and ended up on May 24, 2013.



Figure 6. The semicylinder metal plate

Soil measurements were carried out with a JW 3000 model assay balance measuring in $0.1 \mathrm{~g}$ of precision. A Garmin GPSMAP 60CSx model GPS device was used to determine coordinates and altitudes. The fundamental principles of the geonet application were based on the application examples of erosion control blankets (Figure 7). 


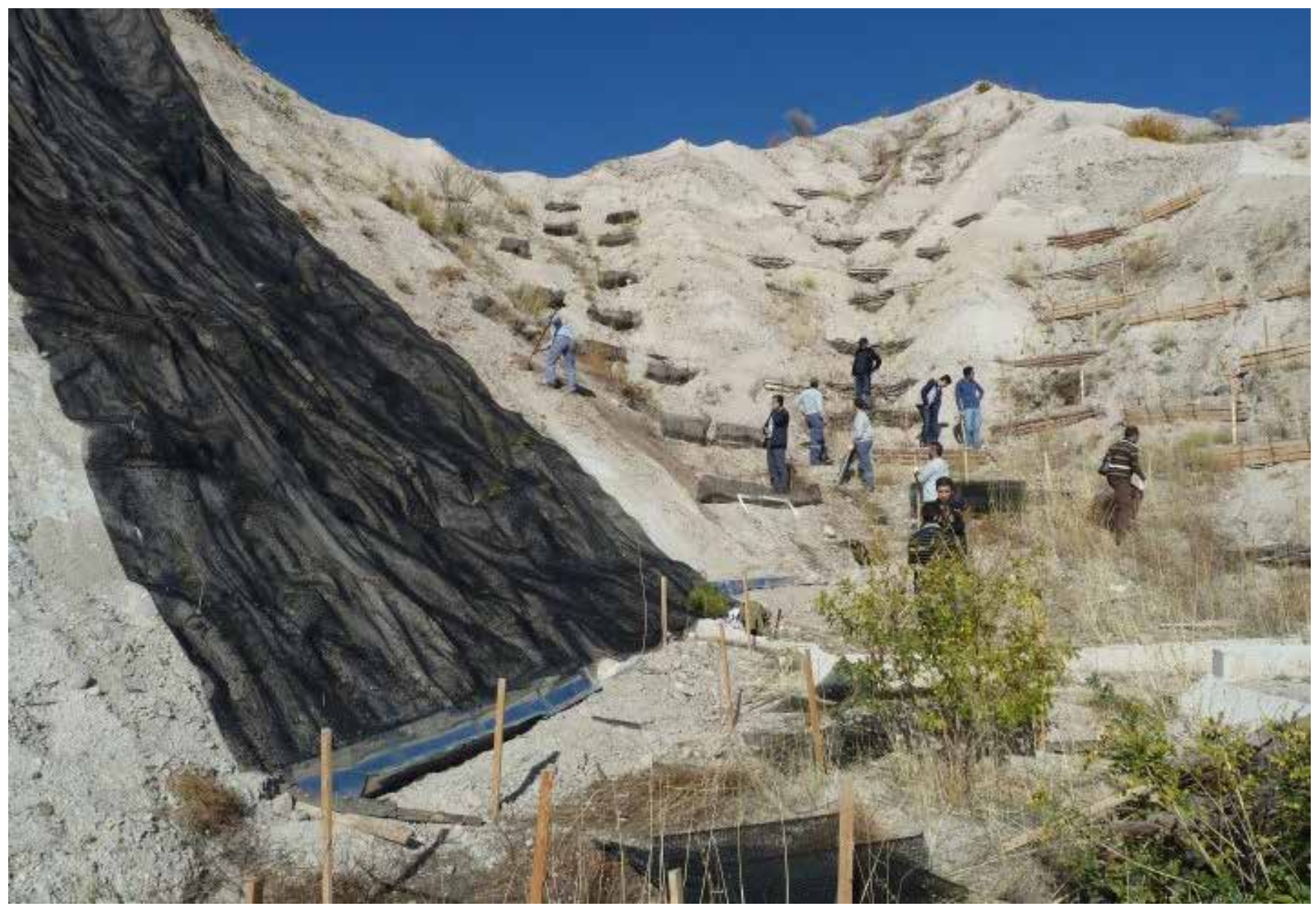

Figure 7. The application of geonet

The quantity of soil saved in the metal plates started to be measured on September 10,2012 and the

\section{RESULTS AND DISCUSSION}

The amount of sediment yield in the geonet application

It has been observed that the quantity of leaking soil has increased due to starting of precipitation. It measurements were recorded by being periodically carried out until May 24, 2013.

is thought that erosive precipitation has significant influence on increasing of the quantity of soil carried. While the increase was high in the first measurements, it has been on the decline since February and March when the germination started (Table 5).

Table 5. The precipitation data of months measured

\begin{tabular}{|l|c|c|c|c|c|c|c|c|c|}
\hline \multicolumn{7}{|c|}{ PRECIPITATION (mm) } \\
\hline & \multicolumn{7}{|c|}{2012} & \multicolumn{3}{|c|}{2013} \\
\hline Period & Sep. & Oct. & Nov. & Dec. & Jan. & Feb. & Mar. & Apr. & May. \\
\hline Total Precipitation & 12.4 & 15.2 & 21.0 & 125.2 & 97,2 & 40 & 58,4 & 38,6 & 27,2 \\
\hline Maximum Precipitation & 12.4 & 4.4 & 9.8 & 21.0 & 42.0 & 13,6 & 19,4 & 12,4 & 9,2 \\
\hline
\end{tabular}


The independent samples t-test was applied for the purpose of identifying whether there was a significant difference between the site where the geonet was used and the site without the geonet. The results were displayed on Table 6.

Table 6. The averages of the site with the geonet and the site without the geonet - the results of the t-test

\begin{tabular}{|l|c|c|c|c|c|}
\hline \multicolumn{1}{|c|}{ Groups } & N & Mean & Sd & t & The Significance Level \\
\hline Geonet Application & 16 & 375,93 & 76,298 & $-16,560$ & $\mathrm{P}<0.05$ \\
\hline Control & 16 & 1522,31 & 266,175 & $-16,560$ & \\
\hline
\end{tabular}

As Table 6 is dealt with, it was observed that there is a difference between the geonet application site $(375,93)$ and the control site $(1522,31)$. A significant difference at $\mathrm{P}<.05$ level was detected as a result of the $\mathrm{t}$-test $(\mathrm{t}=-16,560)$ which was applied to identify the difference statistically. According to the results of the measurement, the loss of soil from the control site was in four-fold of the geonet application site (Table 7).

Table 7. The amount of sediment yield in control and geonet application sites moved by precipitation.

\begin{tabular}{|c|c|c|c|c|}
\hline Measurement & Month & Date & Geonet Application (gr) & Control (gr) \\
\hline 1 & SEPTEMBER & 10.09 .2012 & 432 & 1487 \\
\hline 2 & SEPTEMBER & 22.09 .2012 & 458 & 1574 \\
\hline 3 & OCTOBER & 06.10 .2012 & 403 & 1206 \\
\hline 4 & OCTOBER & 20.10 .2012 & 358 & 1354 \\
\hline 5 & NOVEMBER & 01.11 .2012 & 378 & 1325 \\
\hline 6 & DECEMBER & 20.12 .2012 & 505 & 1957 \\
\hline 7 & JANUARY & 05.01 .2013 & 495 & 1653 \\
\hline 8 & JANUARY & 20.01 .2013 & 446 & 1663 \\
\hline 9 & FEBRUARY & 07.02 .2013 & 308 & 1207 \\
\hline 10 & FEBRUARY & 22.02 .2013 & 250 & 1265 \\
\hline 11 & MARCH & 09.03 .2013 & 314 & 1278 \\
\hline 12 & MARCH & 23.03 .2013 & 289 & 1371 \\
\hline 13 & APRIL & 10.04 .2013 & 357 & 1987 \\
\hline 14 & APRIL & 30.04 .2013 & 286 & 1967 \\
\hline 15 & MAY & 14.05 .2013 & 358 & 1574 \\
\hline 16 & MAY & 24.05 .2013 & 378 & 1489 \\
\hline \multicolumn{3}{|l|}{ TOTAL } & 6015 & 24357 \\
\hline \multicolumn{3}{|c|}{ THE AVERAGE of the MEASUREMENT } & 375.9 & 1522.3 \\
\hline
\end{tabular}


While a low difference was observed between precipitation increase or decrease and the amount of sediment yield in the geonet application site, an increase in the amount of sediment yield was observed in the control site due to the effects of precipitation (Table 8).

Table 8. The correlation between the amount of total precipitation and the amount of accumulated sediment yield

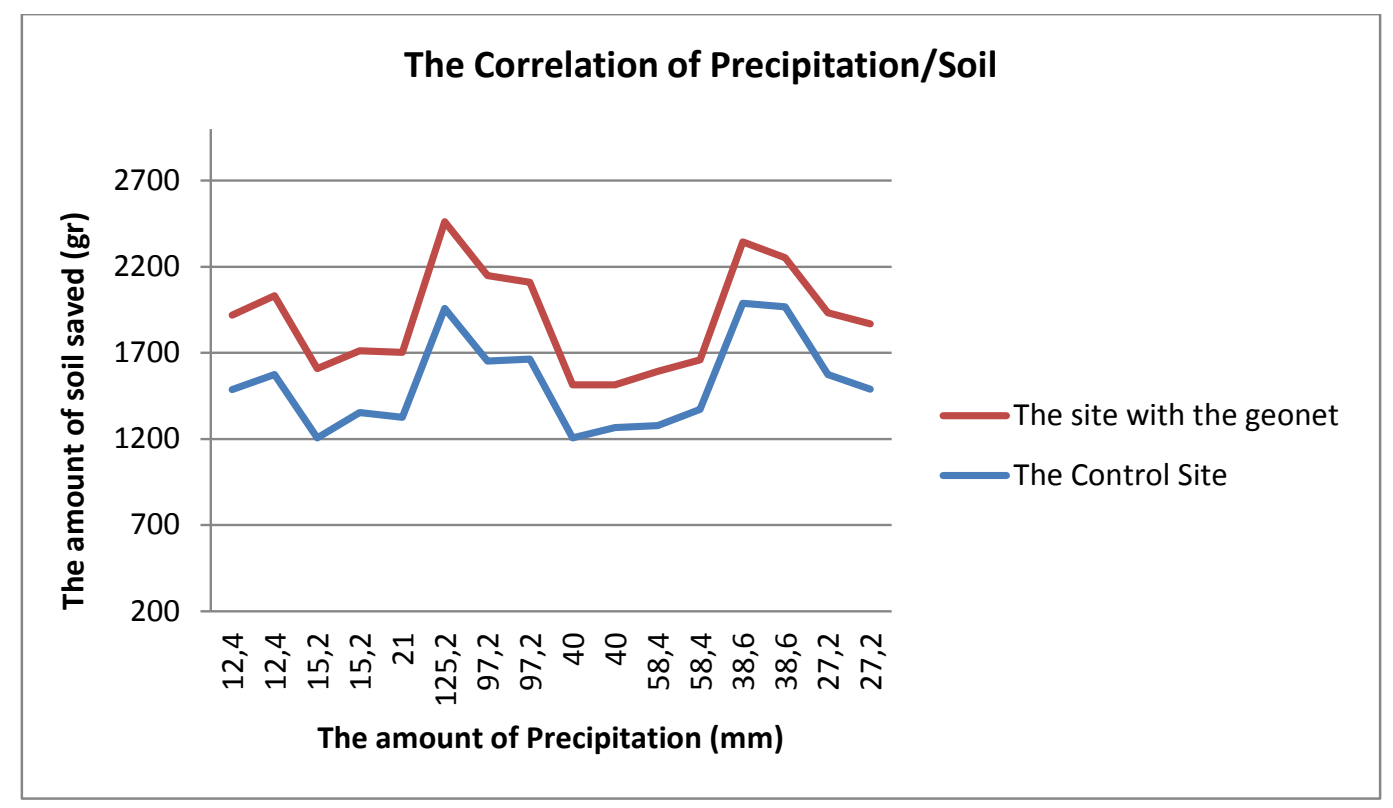

An appropriate environment was created because of saving soil. As it is observed on Figure 8, lots of herbaceous plants started to develop. Hence, both the geonet itself and the growing newly vegetation cover had influence on saving soil on the ground. Furthermore, both the view of the product and the developing vegetation cover positively affected the visuallity, too.
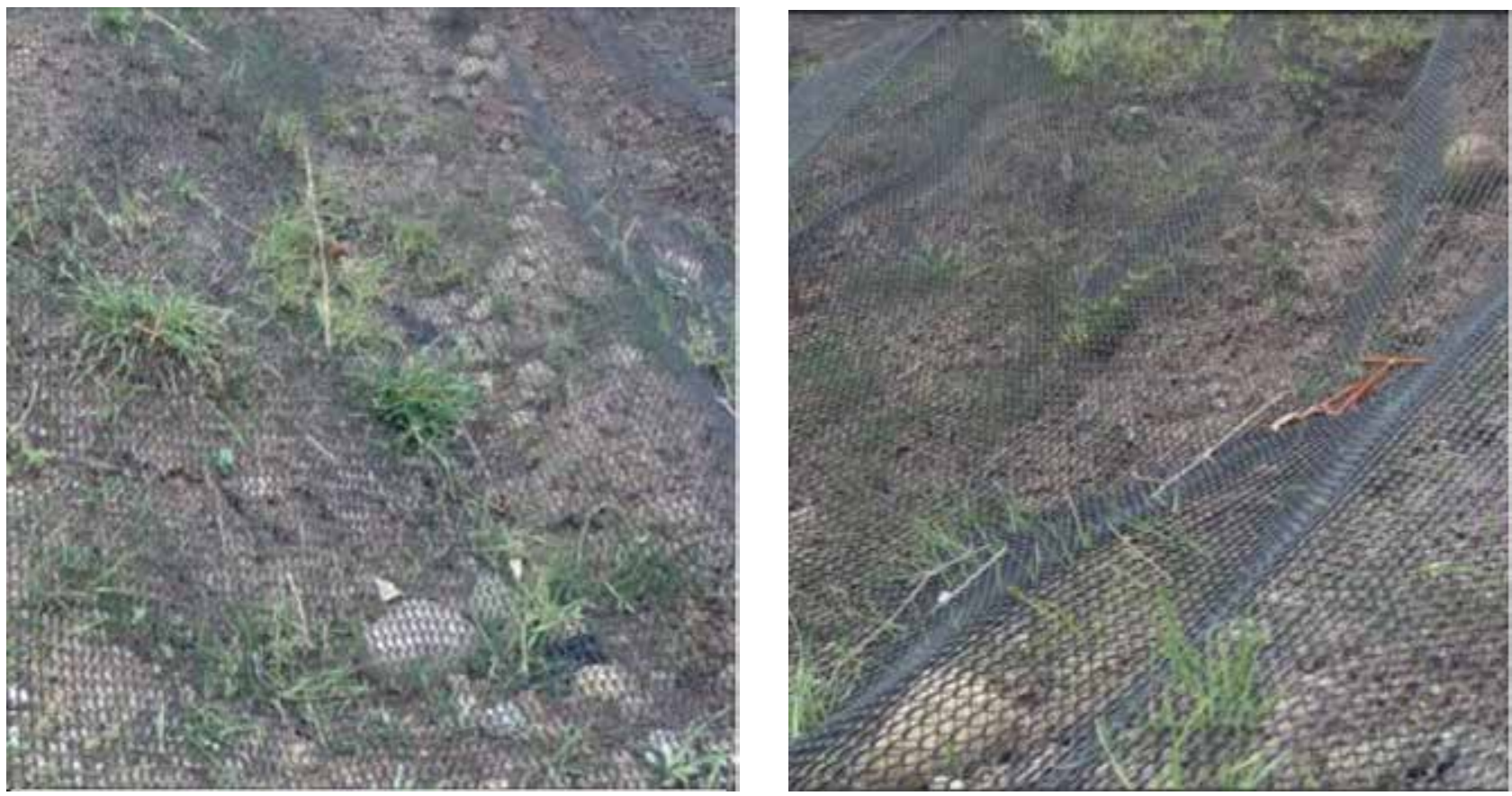

Figure 8. Start up of germination under the geonet 
The vegetation cover is getting lost day by day due to erosion as well as the topographic structure, climatic conditions, the interventions of humankinds, overurbanization, changings in climatic conditions, and drought. Especially inclined lands are eroded because of the factors such as rain and wind so that it causes alive soil to get lost.

Erosion is increasing because of the reasons such as destroying forest lands, overgrazing on pastures, adverse land use, and irregular rural habitation (Anonim 2015). The result of erosion is to become a desert. The distruption of the vegetation cover, the exposure of soil to erosion, the decrease of springs result in erosion. Lots of lands in Turkey are under the desertification threat. Although erosion occurs as a result of natural factors, humankinds speed up the process with their interventions. Even, it is known that the acceleration goes up in 10-40 fold with the effects of humankinds (Blanco et al. 2010). Thus, administrative and educational precautions play an essential role in controling erosion as well as technical precautions.

Natural or artificial elements should be used in order to avoid erosion as soon as possible. Natural methods are always preferred as they are cheaper and more long-lasting in comparison with artificial ones. It will be a permanent solution especially when inclined lands which are wide in terms of field are stabilized with herbal methods. As permanent solutions, natural methods such as covering land with grass clods, mulching, alive woven fences, and blankets made of fodder are frequently used. Besides, artificial methods in which geosynthetic products the usage area of which has become widespread especially in last years are used and are preferred.

As measurements and the amount of precipitation are taken into consideration, it is observed that the loss of soil has increased with the increase of precipitation. For example, while the loss of soil is high in the site without the geonet in December when total of precipitation is high, the loss is relatively low in September and October when total of precipitation is low. Besides, while the loss of soil is low during the period when the site is covered with snow, the loss is at the highest level in April when both snow melts and also rain increases. With the help of the work carried out in the inclined field, it is determined that soil is saved more in the site with the geonet than in the site without the geonet. The application technically yields a possitive result that the site with the geonet saves soil in four fold in comparison with the site without the geonet. Geotextiles which are used in or on the surface course of slopes avoid the course on the surface to leak, to get deformed and make erosion minimised. Geosynthetic products in a shape of a rough net provide seeds with an appropriate environment to sprout. Hence, it is ensured that the vegetation cover rapidly grow on the slope (Dernek 1998).

The usage areas of geosythetic products are increasing day by day as alternative materials to conventional construction ones both in the world and also in Turkey thanks to their technical superiorities and low costs. Geosynthetic products which provide significant technical and economical advantages when they are appropriately used should be applied by considering their engineering features according to the target application. Thus, it is a must to make a preliminary investigation in detail in the research site to minimise potential mistakes as much as possible (Wasti 2007). For example, highstrength geosynthetic products should be used on erosion control works. A geonet product in erosion control and slope stabilization should be especially preferred on the purpose of carrying out filtration, drainage, and protection.

The usage of geosynthetic products are much more in constructional engineering compared to other occupational disciplines in Turkey. In this regard, their usage should be generalised in other relevant disciplines, especially in forestry and landscape applications.

The works done by international and national geosynthetic organizations, universities, and producers of geosynthetic products should be considered multidisciplinary and effectively handed in sharers. It should be identified how geosythetic products are affected by specific conditions such as 
climatic and topographic ones with the help of the pilot scheme. The landscape ecology is contributed by taking precautions for soil reinforcement, enhancing microclimate and water system and boosting ecological variety (Çelem 1988). The research site should be investigated well for the target works. Geosynthetic products rapidly propose over

\section{CONCLUSION}

The Geonet product was tested and analyzed at a glacis with a slope of $74 \%$ within the boundaries of the district of Çamlıdere of the province of Ankara.

The application technically yields a possitive result that the site with the geonet saves soil in four fold in comparison with the site without the geonet. While the loss of soil is low during the period when the site is covered with snow, the loss is at the highest level in April when both snow melts and also rain increases.

\section{REFERENCES}

Anonim 2013a, Çölleşme ve Erozyonla Mücadele Genel Müdürlüğü , www.cem.gov.tr (10.08.2013).

Anonim 2013 b, www.tema.org.tr (10.07.2013).

Anonim 2013 c, http://aris.cob.gov.tr (11.08.2013).

Anonim 2013 d, Geoplas ürün tanıtım broşürü.

Anonim 2015. Erozyon ve Sel Kontrolü Uygulamalarında Dikkate Alınacak Hususlarla İlgili Rehber,

T.C. Orman ve Su İşleri Bakanlığı, Çölleşme ve Erozyonla Mücadele Genel Müdürlüğ̈̈, Ankara.

Blanco,Humberto\&Lal,Rattan,2010. "Soil and waterconservation”, Principles of Soil Conservation and Management. Springer. p .2. ISBN 978-90-481-8529-0

Dernek Ö, 1998. Jeosentetikler ve Karayollarında Kullanımı, Yüksek Lisans Tezi, İ.T.Ü. Fen Bilimleri Enstitüsü, İstanbul. specific gradients and in smaller sites. However, the single handed usage of geosythetic products may not provide a permanent solution on erosion control and slope stabilization works. In such cases, especially biological repair methods should be applied. Planting should be primarily preferred since it is an ecologist solution in slope improvement.

Geosynthetic products rapidly propose over specific gradients and in smaller sites.

However, the single handed usage of geosythetic products may not provide a permanent solution on erosion control and slope stabilization works. In such cases, especially biological repair methods should be applied.

Planting should be primarily preferred since it is an ecologist solution in slope improvement.

Doğan O, 2011. Türkiye'de erozyon sorunu nedenleri ve çözüm önerileri. Bilim ve Aklın Aydınlığında Eğitim, 134, 62-69.

Özgüç M, 1999. TEM Hadımköy-Kınalı Arası Peyzaj Planlaması Üzerinde Görsel Arastırmalar. İTÜ Orman Fak. Der., A Serisi,49. cilt, Sayı:2.

Yılmaz HR, Eskisar T, 2007. Geosentetik Ürünlerin Geoteknik Mühendisligi Sorunlarının Çözümünde Kullanımı ve Saglanan Faydalar, 2. Geoteknik Sempozyumu, 22-23 Kasım 2007, Adana.

Wasti Y, 2007. Geosentetikler - Teori ve Uygulama, Ankara.

Çelem H, 1988. Sorunlu Alanlarda Bitkilendirme Tekniği, Ankara Üniversitesi Ziraat Fakültesi Yayınları: 1047, Ankara.

Myles B, 2006. The need for Geosynthetic Standardsand generic Specifications, İkinci Ulusal Geosentetikler Konferansı, İstanbul No:62 İstanbul, 313-31. 